\title{
Anyagáramok és anyagállományok egy debreceni szolgáltató vállalatnál
}

\section{Material flows and stocks of a service company from Debrecen}

\author{
P. HARAZIN ${ }^{1}$, G.J. DEZSŐ², A. KarCAGI-KovÁts ${ }^{3}$ \\ ${ }^{2}$ Debreceni Egyetem, Gazdaságtudományi Kar, dezso.greta.judit@gmail.com \\ ${ }^{3}$ Debreceni Egyetem, Gazdaságtudományi Kar, Környezetgazdaságtan Tanszék, karcagi- \\ kovats.andrea@econ.unideb.hu \\ 1Debreceni Egyetem, Gazdaságtudományi Kar, Közgazdaságtan Intézet, harazin.piroska@econ.unideb.hu
}

\begin{abstract}
Absztrakt. Az elmúlt 25 évben, egy sor kutatóintézet számos neves tudósa kidolgozott egy új kutatási irányzatot, egy új módszertani családot, az anyagáram elemzést (MFA - Material Flow Analysis). Az MFA jelentőségét az emberiség által létrehozott, gerjesztett anyagáramok mértéke adja. Az MFA növekvő sikerének alapjait egy gyökeresen új, interdiszciplináris, a természet- és társadalomtudományok (ökológia, termodinamika és közgazdaságtan) együttműködését igénylő látásmód adja, azaz nem csak a termelés anyaghatékonyságának és a gerjesztett környezetterhelés vizsgálatának hatásos eszköze, hanem segítséget nyújt a szükséges technológiai innováció irányainak feltárásához, valamint a vizsgált rendszer stratégiai anyagigényei ellátásbiztonságának az elemzéséhez is. Cikkünkben vállalati szintű elemzést végzünk, egy debreceni szolgáltató vállalat 2018-as évre vonatkozó input és outputoldali anyagáramait és anyagállományait elemezzük az MFA módszerével. Az MFA indikátorok naturális dimenzióban ragadják meg a környezetterhelést, azaz tömegben, energiában vagy földterületben mérnek, ennek megfelelően kilogrammban, vagy tonnában mérve mutatjuk be a cég kiinduló anyagállományait és az abban bekövetkezett változásokat, illetve az anyaginputokat.
\end{abstract}

Abstract. Over the past 25 years, many renowned scientists from a number of research institutes have developed a new research method, a new family of methodologies which is the MFA (Material Flow Analysis). The importance of MFA is given by the extent of excited material flows created by mankind. The basis of MFA's growing success is a radically new, interdisciplinary vision that requires collaboration between the natural and social sciences (ecology, thermodynamics, and economics), not only as an effective tool for examining material efficiency of production and environmental pressures, as well as the security of supply of the strategic material requirements of the system under investigation. In our article, we conduct an enterprise-level analysis of the input and output side material flows and materials of a service company in Debrecen for 2018 using the MFA method. MFA indicators capture environmental pressures in a natural dimension, that is, in terms of mass, energy, or land, respectively, in terms of kilograms or tons, of the company's raw materials and their changes, or material inputs. 


\section{Bevezetés}

Az elmúlt 25 évben számos kutatóintézet munkatársai dolgoztak ki egy új kutatási irányzatot, egy új módszertani családot, az anyagáram elemzést (MFA - Material Flow Analysis, továbbiakban MFA). Az MFA jelentőségét az emberiség által létrehozott, gerjesztett anyagáramok mértéke adja, növekvő sikerének alapjait pedig egy gyökeresen új, interdiszciplináris, a természet- és társadalomtudományok (ökológia, termodinamika és közgazdaságtan) együttműködését igénylő látásmód. A következő fejezet az MFA elméleti hátterét mutatja be összefoglaló jelleggel, majd alkalmazásával kapcsolatban vállalati esettanulmányon kerül ismertetésre.

\section{Szakirodalmi háttér}

A társadalom-gazdaság-környezet kapcsolatrendszerének leírására használt legelterjedtebb módszerek azok az eszközök, melyek az úgynevezett anyagáramlás-elemzés módszertani családjába tartoznak. Ezek az eszközök fizikai elszámolást készítenek és ezekhez kapcsolódva mutatószámrendszert hoznak létre a rendszer értékelésére. [1] Az MFA tehát fizikai mérőszámokon alapszik, melyek számszerüsítik a vizsgált folyamatok input és output oldalát [2]. Az MFA egy olyan módszer, mely leírja, vizsgálja, értékeli a rendszer metabolizmusát; feltételeket és eljárásokat definiál azzal a céllal, hogy a rendszer anyagmérlegét létrehozhassuk [3]. Így tehát az MFA modellek magukban foglalják a rendszerbe való bevitelt, az inputot - például a környezetből kitermelt természeti erőforrásokat -, a rendszeren keresztül történő áramlását és a rendszer kimenő, azaz output oldalát például hulladék, visszanyerés és újrafeldolgozás [4], valamint az adott rendszer állományának a növekedését. Egy másik megközelítésben elmondható, hogy az MFA folyamatokat vizsgál, azok „áteresztő” képességére fókuszálva és így jellemzi a kitermelést, kémiai átalakulásokat, gyártást, fogyasztást, hasznosítást és hulladéklerakást (Bringezu \& Moriguchi (2002) hivatkozza [2]). A módszertan az anyagmegmaradás törvényére épít, azaz alapvető összefüggés, hogy a belépő anyag éppen egyenlő a kilépő és a rendszerben felhalmozódó anyag mennyiségével [1]. AZ MFA tehát megfelelő eszköz arra, hogy bármely anyag-alapú rendszer áramait (flow) és állományait (stock) elemezzük, hiszen betekintést ad a vizsgált rendszerbe [3].

Céljaiból a működésére vonatkozólag is információt kapunk, vagyis: (I) segít az anyagáramok és állományok rendszerének felvázolásában egy jól meghatározott, egységes keretnek megfelelően; (II) segít a vizsgált rendszer komplexitásának oly szintű csökkentésében, hogy az a döntéshozatal szempontjából még megfelelő alapot biztosítson. További célja, hogy (III) számszerűen értékelje a releváns áramokat és állományokat és hogy az (IV) eredményeket reprodukálható, érthető és átlátható módon adja közre. Célja továbbá, hogy az (V) eredmények felhasználhatóak legyenek az erőforrás-, környezet- és hulladékmenedzsment alapjaként: különösen a korai nem-megfelelőségek felismerésében, a feladatok priorizálásában, továbbá olyan termékek, folyamatok és rendszerek fejlesztésében, melyek elősegítik a környezetvédelmet, erőforrás-megőrzést és a hulladékmenedzsmentet. [3]

A nemzetgazdaságok teljes metabolizmusának monitorozására szolgálnak a nemzetgazdasági szintű anyagáramlás-számlák (economy-wide Material Flow Accounts/Analisys, EW-MFA, MFA) és az ebből 
képzett mutatók. Ennek módszertanát 2001-ben az Eurostat dolgozta ki, mely módszertan szisztematikusan vizsgálja a fó anyagáramokat, felállítva azok tömegmérlegét (tonnában). [5-6]

Az anyagállományok jelentősége az MFA szakirodalmában csak mintegy 10 éve jelenik meg hangsúlyosan, amikor is a kutatók felismerték, hogy az anyagáramok nagy mértékben és igen rövid idő alatt megváltoztatták a Föld anyagállományainak szerkezetét [7-8]. Az anyagkészletek megfelelő számbavétele tehát elengedhetetlen lenne, hiszen - mindenhol megtalálható - hatalmas felhalmozott és folyamatosan növekvő mennyiségről van szó [9]. Itt emelhető ki az a tény is, miszerint a legtöbb anyag esetében (a víz, az üzemanyag és az élelmiszer kivétel) nem az input vagy az output az, ami a társadalmi szolgáltatást nyújtja, hanem az épületekben, az infrastruktúrában, a jármúvekben, a közszolgáltatásokban és hasonlókban megtestesülő anyagállomány ([10] továbbá [11]). Daniel Müller azt hangsúlyozza, hogy hamarosan ezek az állományok lesznek a legfontosabb nyersanyagforrások, és ezek az állományok jelentős szerepet játszanak az erőforrások és energia fogyasztásában, valamint a hulladékok és emissziók létrehozásában [12]. Hasonlóan érvel Hashimoto, valamint Yokoyama és Nagasaka is, ők azt emelik ki, hogy a technoszférában megtestesülő anyagállományok egyaránt jelenthetnek potenciális hulladékot és másodlagos nyersanyagforrást [13-14].

Felhasználva az Eurostat módszertanát, logikáját, az MFA számos szinten készíthető el. Így kerülhetnek a vállalatok/telephelyek is fókuszába az elemzésnek. Vállalati/telephely szintjén történik a legjellemzőbb input- és az output áramok számbavétele [1], de akár lehetőség van - további bontásra és - folyamat, technológia vagy termék szintjén is elvégezni az elemzést [6]. Korábbi kutatási eredmények azt mutatják, hogy a legtöbb vállalat valamilyen formában méri az input- és output mennyiségeit, azonban a kettő közötti kapcsolatot - így a rendszerszintű, MFA gondolatmenetet - már jóval kevesebben követik nyomon [6]. Egy finn kutatás [2] kimutatta, hogy 7, a fenntarthatósági elemzést elősegítő eszköz közül az MFA alul marad, ha az átláthatóság, rugalmasság, konszenzuskialakítás és a működtetés szempontrendszerén keresztül vizsgáljuk őket. A kutatás szintén felhívta a figyelmet arra, hogy amennyiben publikus jelentéseken és honlapokon keresztül vizsgáljuk az eszközök használatát, akkor az MFA használata nem jelenik meg (ahogy a vizsgált eszközök többsége sem) [2]. Ennek oka lehet, hogy az MFA nehézségeként értelmezhető az elemzéssel hozott új szemlélet megszilárdítása a szervezetnél, továbbá az MFA-ból képezhető új indikátorok elfogadása, használata - mérési nehézségek, költségtényező - is [6].

Mindezek ellenére azonban az MFA hasznos lehet az anyagok menedzsmentjében, hiszen költséghatékony segítséget nyújt a hulladékok pontos összetételének meghatározásában. A hulladékokkal kapcsolatos információ pedig elengedhetetlen, ha újrahasznosítás, kezelési technológia tervezése van folyamatban. Szintén hasznos az MFA, ha egyes anyagok újrahasznosításával, kezelésével kapcsolatban merül fel igény. Továbbá az MFA hozzájárulhat az olyan termékek tervezéséhez is, melyek hulladékká válásuk során (elavulások során) könnyebben hasznosíthatóak, kezelhetőek. Az MFA által adott anyagmérlegek pedig segítenek a kijelölt célok megvalósításának nyomon követésében, továbbá megmutatják a fejlesztést igénylő helyeket is. [3]

Fontos kiemelni azt is, hogy az MFA használata inputként szolgálhat számos további módszer alkalmazásához. Így említhetjük az életciklus elemzést (LCA), mely számos hasonlóságot mutat az MFA-val, hiszen az LCA is áramokat vizsgál, csak több hatást és szempontot vesz figyelembe [2]; 
említhető az MFCA (Matrial Flow Cost Accounting, Anyagáram költség elszámolás) módszere, mely a költségek helyes meghatározását támogatja azáltal, hogy mennyiségileg és pénzügyi oldalról is nyomon követi a hulladékot, az emissziót és a melléktermékeket [15]. Mindez sok esetben (ld. például a vállalati karbonelszámolást) a vállalati emissziók becsléséhez is alapul szolgál [16-17]. De akár példaként hozható a környezeti teljesítményértékelés is, hiszen számos esetben a környezeti indikátorokra ajánlást adó irodalmakban - müködési - input és output oldali teljesítményindikátorokra tesznek javaslatot [18-19-20]. Brunner és szerzőtársa [3] a „Materials accounting", azaz az anyagok elszámolását (könyvelését) említi, mely nem más, mint az MFA eredményeinek rutinszerü, szisztematikus frissítése pusztán a kulcs áramok és állományok mérésén keresztül. Az MFA tehát alapja a rutinként múködő anyag elszámolásnak, hiszen biztosítja a rendszer megértését, illetve a megfelelő paramétereket (áram, állományok, koncentrációk). A módszer segítségével idősorokat és trendeket tudunk elemezni, azonban kihívás, hogy megtaláljuk azokat a kulcs paramétereket, melyek maximális információt adnak, miközben minimális költségen állítjuk őket elő. [3]

Munkánkban egy multinacionális, debreceni telephellyel múködő szolgáltató vállalat anyagáramainak és anyagállományainak vizsgálata jelenik meg, melyet a következő fejezetben mutatunk be.

\section{Vállalati esettanulmány ${ }^{1}$}

\subsection{A vizsgált vállalat jellemzése}

A T-Systems egy német globális informatikai szolgáltató és tanácsadó cég, amelynek székhelye Frankfurtban található. 2000-ben alapították, a Deutsche Telekom leányvállalataként. [22] Az IT Services Hungary (ITSH) a T-Systems International magyarországi leányvállalata. Budapesti, debreceni, pécsi és szegedi szolgáltató-központjai rendszerintegrációs és üzemeltetési területeken szolgálják ki a nemzetközi ügyfeleket, de kínálatukban többek között az összes, széles körben alkalmazott szoftver- és hardverplatform szolgáltatásai, távoli és helyi szerverüzemeltetés, valamint hálózatmenedzselés és hálózatfelügyelet is megtalálható. [21]

A cég Budapest után 2007 júniusában nyitotta meg második szolgáltató központját, Debrecenben. Azért született a döntés Debrecen mellett, mert a vállalat itt találta meg azt a fejlődő, lendületes közeget, ahol tehetséges, motivált fiatalokkal és kiváló szakemberekkel lehetséges sikeres vállalatot építeni [21].

Jelenleg 1890 fő dolgozik a debreceni telephelyen, ahol a következő főbb tevékenységeket látják el: koncepció-kidolgozás; komplex informatikai rendszerek és teljes informatikai infrastruktúrák létrehozatala és üzemeltetése; alkalmazási szoftverek, vállalati informatikai biztonsági rendszerek kifejlesztése; informatikai rendszerek felügyelete; informatikai alkalmazások és rendszerek kifejlesztése [21].

\footnotetext{
${ }^{1}$ Az esettanulmány alapjait Dezső Gréta Judit az „Anyagáram-elemzés az IT Services Hungary Kft. debreceni leányvállalatánál" címú szakdolgozata adja
} 
Az ITSH Kft. fenntartható fejlődés érdekében tett lépéseit is érdemes megemlíteni. Folyamatos a környezetvédelmi jogszabályok nyomon követése és betartatása, továbbá figyelmet fordítanak a környezet megóvására, a környezeti állapot javítására. A környezetszennyezés megelőzése és a környezeti hatások csökkentése érdekében környezeti célokat tűznek ki, ezek elérését előtérbe helyezik, majd kiértékelik. [22] Az IT Services Hungary Kft. Magyarország legnagyobb infokommunikációs munkaadójaként számos területen támogatja a felelős vállalatirányítás megvalósítását. Az ITSH Kft.-nél a környezeti tevékenységeket a rendszerszerű múködés jellemzi az EMAS rendszeren és ISO 14001-es szabványon keresztül. [23]

\subsection{Az elemzés keretei}

Az elemzés célja volt, hogy egy konkrét esetben kerüljön alkalmazásra az anyagáram-elemzés módszertana: cél tehát a debreceni IT Services Hungary Kft. ${ }^{2}$ anyagmérlegének összeállítása, melyhez a 2018-as gazdasági év adott alapot. Jelen munkában azonban mindösszesen az elemzés vázának (modellalkotás) bemutatásra nyílik lehetőség.

Az anyagmérleg összeállításának alapját primer és szekunder kutatás adta. Személyes megkérdezésekre, interjúkra került sor, így az illetékes vezetőktől származó információk jelentették az elsődleges forrást. Szekunder adatokat a szervezetnél rendelkezésre álló, a különböző szervezeti egységek - így Facility Management, Asset Management, Field Service Local Helpdesk és az Uniszol Kft - által rendelkezésre adott táblázatok, regiszterek, bizonylatok nyújtottak.

Az elemzési terület lehatárolása fontos lépés volt, melyet a rendelkezésre álló információ mennyisége is befolyásolt. Az elemzéshez öt - anyagáram - terület került meghatározásra (így az ITSH tevékenységeinek kb. 80\%-a került lefedésre): (1) Irodai bútorok, berendezési tárgyak; (2) IT Eszközök - Hardware-ek; (3) Nyomtatók (beleértve a tonereket és papírokat); (4) Konyhai eszközök („teakonyha”); (5) Tisztítószerek \& takarító eszközök. (Információhiány miatt az elemzés nem foglalkozik például a büfé, „,kifőzde”, energiaellátás áramaival és állományaival.)

\subsection{Az elemzés eredményei}

A munkafolyamatban a végleges anyagmérleg összeállítását számos elemzés, számítás előzte meg. A következő regiszterek készültek el: Konyhai eszközök listája tömeggel; Konyhai eszközök listája darabonként tömeggel és összes darabszámmal; Tisztítószerek listája tömeggel; Takarító eszközök listája tömeggel; Vállalati szintű input-output elemzés; Kezdő állományok csoportosítása anyagkategóriánként; 2018 januári nyitó készlet; Nyitó készlet és kiselejtezett darabok összehasonlítása; Nyitó készlet (január) és megmaradó készlet (december) összehasonlítása.

Az elemzés során a selejtezés témája külön szerepelt: fontos megemlíteni, hogy a cég a kiselejtezett informatikai, IT eszközökkel külön foglalkozik, azok szelektív gyűjtése és megfelelő elszállítása is biztosított. A hulladékgyüjtéssel kapcsolatos információk is összegyüjtésre kerültek: az épületben minden folyosón, konyhában, irodában vannak szelektív hulladékgyűjtő kukák, melyeket a dolgozók

${ }^{2} \mathrm{~A}$ fejezet további részében az ITSH rövidítés alatt a debreceni telephelyet értjük 
tudatosan használnak; a tisztításhoz kapcsolódó vegyszerek csomagolásának hulladékgyűjtése is megoldott. A vállalat minden év végén tart egy nagy leltárt, ahol kiselejtezésre kerülnek az elmúlt évben elhasználódott, tönkrement, munkavégzésre alkalmatlan tárgyi eszközök - ezek későbbi életéről is gondoskodik a cég, alkalmazottai jutányos áron juthatnak hozzájuk, vagy éppen adományként adják újrahasználatra [24].

Mindezekből lehetőség nyílik a vizsgált területekre vonatkozó anyagmérleg összeállítására, mely jelen munkában mindösszesen az anyagmérleg modelljére szűkül. Ezt szemlélteti az 1. ábra. Az anyagmérleg modellje tartalmazza az egyes kategóriák nyitó értékét és a vizsgált időszak alatti összes felhasználást. A modellből az is láthatóvá válik, hogy a 2018-as év végén ezen inputok mekkora része maradt állományként használatban a szervezetnél és mekkora része távozott outputként a rendszerből.

Az MFA szakirodalmi áttekintése során említésre került az anyagállományok kiemelt szerepe. Ennek megfelelően az elemzésben a vizsgált anyagáramokon kívül érdekes lehet vizsgálni az épület és az őt körülvevő környezet tömegét is. A számításhoz alapot adott az épület alapterülete, kialakítása is, és a betonpillérek, födémek, végül a körítőfalak tömegével kapcsolatos becslések. A számítás során először lehetőség nyílott az előbbiek térfogatának becslésére, majd a beton sűrűségét felhasználva, a tömeg becslésére. Az épület tömege tehát 15 520,5 tonna, míg a parkoló és a hozzá tartozó út 9 479,4 tonna. Összességében elmondható, hogy ezek 25000 tonna tömegủ anyagállományként jelennek meg.

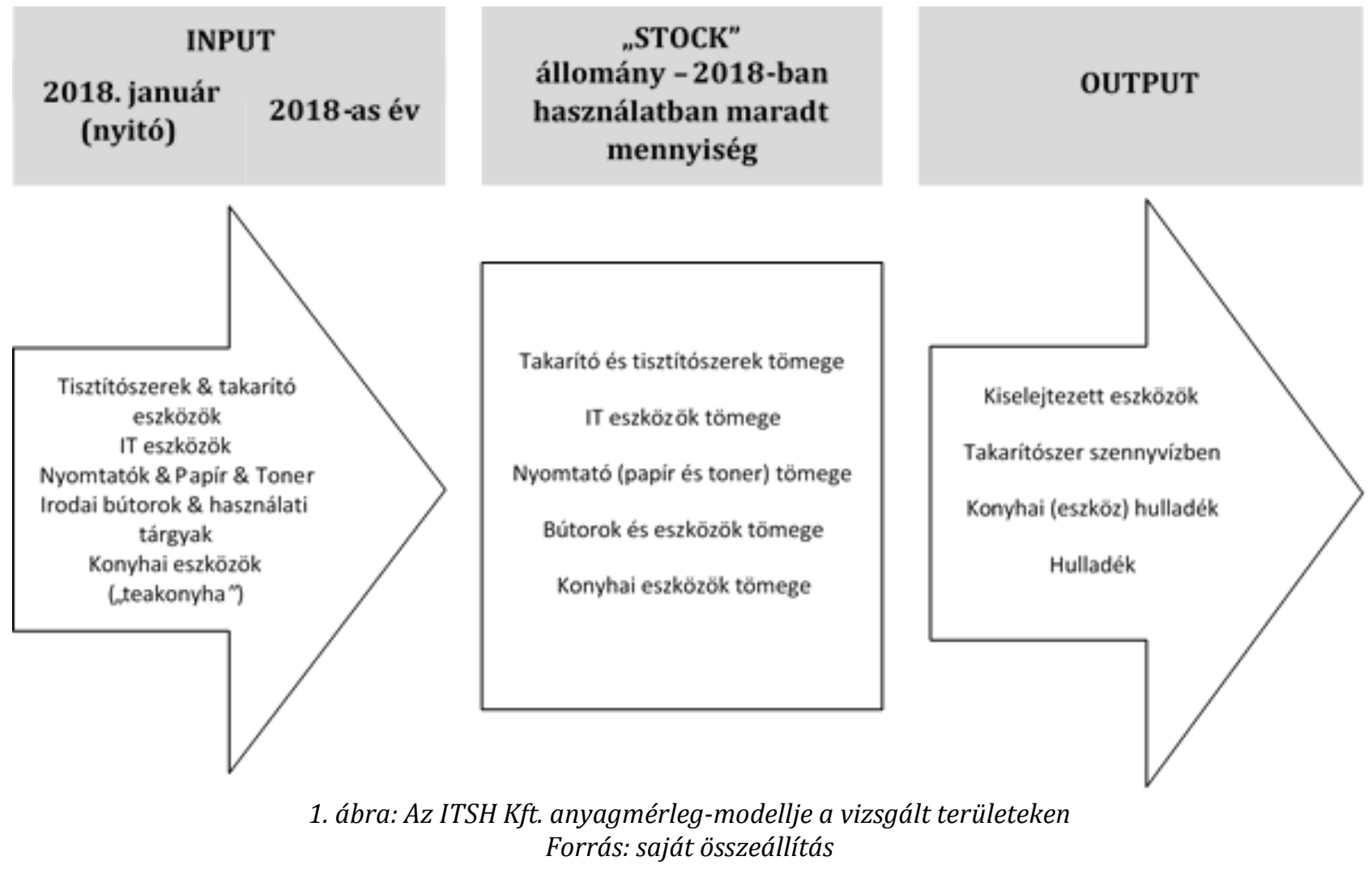

Ahogyan az Eurostat ajánlásában számos indikátor jelenik meg a nemzetgazdasági anyagáramok és állományok jellemzésére, úgy a vállat szintjén is lehetőség nyílik - felhasználva az anyagmérleg adatait - különböző indikátorok generálására. 
Egy lehetséges indikátorkészletről ad összefoglalást a 2. ábra. Első lépésben - az anyagmegmaradás törvényére építve - az anyagmérlegből közvetlenül kinyert információk alakíthatóak indikátorokká, melyek lehetnek az inputtal, az állománnyal és az outputtal kapcsolatos - aggregált - indikátorok. A vállalati példából látható, hogy az adott évi nyitó értékek figyelembevételével a vállalat valós „stock” értékéről kaphatunk információt. Ezek az indikátorok relatívvá tehetőek, ha például a tömegeket az alkalmazottak létszámához viszonyítjuk. Az épület állományával kapcsolatos becslések is felírhatóak indikátorok formájában, továbbá mindezekből képezhetőek további abszolút és relatív mutatók.

\section{Jövőbeli lehetőségek}

Kutatásunk első eredményét, a debreceni IT Services Hungary Kft 2018-as évre vonatkozó anyagáramaiból és anyagállományaiból képzett anyagmérleg modelljét közöltük. Választásunk a vállalat tekintetében tudatos volt abból a szempontból, hogy a fejlett országok gazdasági teljesítményének közel kétharmadát a szolgáltató szektor adja, így ezek az eredmények nem csak makro szinten jelentősek, hanem a későbbiekben jó összehasonlítási alapot nyújtanak más szolgáltató, vagy termelő vállalat anyaghatékonyságának vizsgálata során. Az anyaghatékonyság meghatározásához elengedhetetlenek az indikátorok, melyeket a vállalat anyagmérlegéből képeztünk. Amennyiben a vállalatok pénzügyi eredményeiket is rendelkezésre bocsájtják, úgy különböző ágazatok összehasonlítása esetén még izgalmasabb mutatókat kaphatunk, ha az anyagáramokat és állományokat a kibocsátás egységére vetítjük. A magyar gazdaság egységnyi GDP előállításához 1,15 tonna anyagot használ fel. A továbbiakban megválaszolandó kérdés, hogy ez a mennyiség hogyan oszlik meg a különböző szektorok között. Elemzésünk eredményeit felhasználva lehetőség nyílik a jövőben idősorok készítésére, az anyagáramok és -állományok időbeni változásának elemzésre és következtetések levonására.

\begin{tabular}{|c|}
\hline Indikátorok az anyagmérlegből \\
\hline INPUT INDIKÁTOROK \\
\hline 2018 januári nyitó eszközállomány [t] \\
\hline 2018-ban felhasznált összes input [t] \\
\hline $\begin{array}{l}\text { Egy foore vetített inputfelhasználás 2018- } \\
\text { ban [t/fö] }\end{array}$ \\
\hline ÁLLOMÁNY INDIKÁTOROK \\
\hline $\begin{array}{l}2018 \text { végén állományban, használatban } \\
\text { maradt eszközök tömege }[\mathrm{t}]\end{array}$ \\
\hline $\begin{array}{l}\text { Egy főre vetített állományban, } \\
\text { használatban maradt eszközök tömege } \\
\text { [t/fő] }\end{array}$ \\
\hline OUTPUT INDIKÁTOROK \\
\hline Keletkezett hulladék mennyisége $[\mathrm{t}]$ \\
\hline $\begin{array}{l}\text { Egy före vetített kel etkezett } \\
\text { hulladékmennyiség [t/fö] }\end{array}$ \\
\hline
\end{tabular}

\section{További állományszámítás}

\begin{tabular}{|l|}
\hline Épület becsült tömege $[\mathrm{t}]$ \\
\hline Egy före vetített épülettömeg [t/fő] \\
\hline $\begin{array}{l}\text { Az épül et és a hozzá tartozó } \\
\text { parkolórész becsült össztömege [t] }\end{array}$ \\
\hline
\end{tabular}

Állomány, használatban maradt

eszközök (2018) /összes input (2018) $[\mathrm{t} / \mathrm{t}]$

Állomány, használatban maradt eszköz (2018) + épület és parkoló tömege [t]

Keletkezett hulladék (2018)/összes input (2018) [t/t]

2. Ábra: Lehetséges indikátorok az anyagmérlegen alapulva

Forrás: saját összeállítás 


\section{Hivatkozások}

[1] M. Herczeg, 2008, Anyagáramok elemzése a társadalmi és ipari metabolizmus különböző szintjein. PhD értekezés. BME. Budapest.

[2] T. Myllyviita, R. Antikainen, P. Leskinen, 2017, Sustainability assessment tools - their comprehensiveness and utilisation in company-level sustainability assessments in Finland, International Journal of Sustainable Development \& World Ecology, 24:3, 236-247, DOI: 10.1080/13504509.2016.1204636

[3] P. H. Brunner, H. Rechberger, 2004, Practical Handbook of Material Flow Analysis; Advanced Methods in Resource and Waste Management; LWEIS PUBLISHERS, 2004

[4] I.Pomázi, E. Szabó, 2006, A társadalmi metabolizmus, L'Harmattan, Budapest

[5] K. Kósi, L. Valkó, 2006, Környezetmenedzsment, Typotex, Budapest

[6] A. Torma, 2007, A környezeti teljesítményértékelés aggregáló módszerei és az anyagáram-elemzés kapcsolatrendszere. Egy integrált vállalati modell megalapozása. PhD értekezés. BME. Budapest.

[7] A. Karcagi-Kováts, I. Kuti, 2012, A készletek általános elmélete és a fenntartható fejlődés. Magyar TUDOMẤNY 173.: 2 pp. 216-225., 10 p.

[8] I. Kuti, A. Karcagi-Kováts, M. Dombi, 2013, Az anyagállományok és az ökológiai gazdaságtan mérési problémái pp. 220-234., 15 p. In: Tóth, Éva (szerk.) A jövő farmja. 55. Georgikon Napok nemzetközi tudományos konferencia.

[9] P. H. Brunner, H. Rechberger, 2002, Practical Handbook of Material Flow Analysis. ISBN 0-20359141-0

[10] P. H. Brunner 2016, Material Flow Analysis as a Decision Support Tool for Waste Management: A Literature Review. Journal of Industrial Ecology 19(5)

[11] M. Dombi; A. Karcagi-Kováts, I. Kuti, 2015, Egyes közlekedési hálózatok természeti erőforrás- és költséghatékonyságáról. Közlekedéstudományi Szemle 6 pp. 4-12., 9 p.

[12] D.B. Müller, 2006, Stock dynamics for forecasting material flows-Case study for housing in The Netherlands. Ecological Economics 59, pp. 142-156

[13] S. Hashimoto, 2005, Material Stock Accounts and Resource/Waste Management.

[14] K. Yokoyama, T. Nagasaka, 2007, The Case Study of National-scale Material Flow Assessment-the Japan Experience. Environmental and Energy International Conference, Taipei, Taiwan, 17 $\begin{array}{lllll}\text { January, 2007, } & \text { Conference presentation } & \text { (ppt), } & 46 & \text { p. }\end{array}$ http://www.ctci.org.tw/public/Attachment/9110141919622.pdf

[15] T. Viere, M. Prox, 2010, The Internalisation of Material Flow Cost Accounting; Newsletter; Centre for Sustainability Management; www.leuphana.de/csm; 01/2010

[16] G. Tóth, C. Szigeti, G. Harangozó, D.R: Szabó, 2018, Ecological Footprint at the Micro-Scale-How It Can Save Costs: The Case of ENPRO. Resources 2018, 7(3), 45; https://doi.org/10.3390/resources7030045

[17] M. Csutora, G. Harangozó, 2019, Széndioxid-elszámolás a hálózati gazdaságban. Vezetéstudomány, 50(9), 26-39.

[18] ISO 14031, 2013, Environmental management -- Environmental performance evaluation -Guidelines. ISO

[19] G. Harangozó, 2008, Mitől zöld egy vállalat-avagy mit is jelent a jó környezeti teljesítmény? Vezetéstudomány. 39(1), 27-36. 
International Journal of Engineering and Management Sciences (IJEMS) Vol. 4. (2019). No. 4 DOI: 10.21791/IJEMS.2019.4.35.

[20] P. Harazin, 2017, A fenntarthatóság dimenzióiban végzett teljesítményértékelés korszerü eszközei, PhD értekezés, BME, Budapest

[21] ITSH Hungary 2010 https://www.it-services.hu/our-services/?lang=en

[22] T-Systems 2018 https://www.t-systems.com/

[23] ITSH 2018 https://www.it-services.hu/bemutatkozas/telephelyeink/

[24] ITSH 2019 - Facility Management 